\title{
Rearing method and life-table data for the cocoa mirid bug Sahlbergella singularis Haglund (Hemiptera: Miridae)
}

\author{
R. Babin ${ }^{1,2}$, D. H. B. Bisseleua ${ }^{3,4}$, L. Dibog ${ }^{4}$ \& J. P. Lumaret $^{2}$ \\ 1 CIRAD Regional Management, BP 2572, Yaoundé, Cameroon \\ 2 Arthropod Team, CEFE, UMR 5175, University of Montpellier, Montpellier, France \\ 3 Department of Crop Science, Entomological Section, Georg-August-University, Goettingen, Germany \\ 4 IRAD, BP 2067, Yaoundé, Cameroon
}

\author{
Keywords \\ Distantiella theobroma, cocoa mirids, \\ fecundity, humidity, intrinsic rate of increase, \\ net reproductive rate

\section{Correspondence \\ R. Babin, CIRAD Regional Management, BP 2572, Yaoundé, Cameroon. E-mail: regis.babin@cirad.fr}

Received: May 19, 2007; accepted: December 18, 2007

doi: 10.1111/j.1439-0418.2008.01273.x

\begin{abstract}
The mirid bug Sahlbergella singularis feeds on cocoa pods and shoots, causing considerable crop losses. As laboratory experimentation requires numerous insects, this study aimed at improving available rearing method of $S$. singularis for Cameroon. Fifty second to fifth nymphal stages were collected at a cocoa farm and reared to the adult stage on cocoa pods in an insectary $\left(T=24.7 \pm 0.9^{\circ} \mathrm{C}, \mathrm{RH}=84.5 \pm 6.8 \%\right.$, photoperiod: $12: 12 \mathrm{~L}: \mathrm{D})$. Newly emerged females were confined for 5-6 days on cocoa twigs for sexual maturation and each female paired with a male for $24 \mathrm{~h}$. The pairs were returned to the field and enclosed in mousseline sleeves on attached cocoa pods, for egg laying. After 16 days (expected egg lifetime), the sleeve cages were checked daily to detect newly hatched nymphs. Then, the pods were collected and brought to the insectary, where nymphs continued to emerge and develop into adults. Our method allowed the production of $14.6 \pm 6.7$ nymphs per female per generation, for 15 consecutive generations. Nymphal survival was calculated to be $68.2 \%$ and the mean duration of the nymphal development was measured at $22.7 \pm 3.1$ days. The rearing performance was evaluated using life-table calculations. The net reproductive rate $\left(R_{0}\right)$ was 6.59 ; the intrinsic rate of increase $(r)$ was 0.037 per female per day with a population doubling time $\left(T_{\mathrm{d}}\right)$ of 18.9 days. On average each female contributed 9.70 individuals to the population given a mean generation time $\left(T_{\mathrm{c}}\right)$ of 52.1 days. The percentage of reproductive females and the mean number of nymphs per female were significantly different between generations, with $86.8 \%$ and $18.1 \%$ in generation G7 as compared to $45.8 \%$ and $8.4 \%$ for generation G5, respectively. As rainfall showed concordant variations during the period of investigation, we discuss the impact of this factor on mirid fecundity.
\end{abstract}

\section{Introduction}

The two mirid bugs Sahlbergella singularis Haglund and Distantiella theobroma Distant are the major pests of cocoa in West Africa. Mirids feed on pods and shoots and cause the drying up of leaves and a quick destruction of the cocoa canopy. Feeding lesions usually develop into cankers that weaken the tree and enable the development of parasitic fungi in the tree. The combination of mirid and fungal damage results in a quick decline of farms, when control measures are inadequate (Crowdy 1947; Williams 1953a). Yield losses are estimated at about 30-40\% (Entwistle 1972; Collingwood 1977; Lavabre 1977). 
The development of novel-integrated pest management strategies implies intensive laboratory experimentation, which requires a large number of insects. However, low densities and seasonal fluctuations of on-farm mirid populations make field collections unpractical (Williams 1953b; Lotodé 1969; Youdeowei 1971; Nwana and Youdeowei 1978). In the past, many rearing attempts were not successful (Raw 1959; Prins 1964; Lavabre 1969; Piart 1970; Cross and King 1971; Kumar and Ansari 1974). The fragility of immature stages and the high toxicity of mirid saliva to cocoa tissues could explain these failures (Piart 1977). In 1959, Raw proposed the first rearing method for $S$. singularis and D. theobroma. Cocoa seedlings of about 6-9 months old were used for egg laying. Rearing of nymphs was done on collected pods. Raw's method has been slightly improved by Prins (1964) and Houillier (1964) for D. theobroma and by Youdeowei (1964) for S. singularis. However, their technique remained unproductive and costly with regard to labour and plant material. In 1970, Piart succeeded in rearing $D$. theobroma, for 10 generations, on green twigs of Ceiba pentandra (Bombacaceae). More recently, Padi et al. (1996) showed that Desplatsia dewevrei (Tiliaceae) is an alternative host plant for $S$. singularis and could be used for rearing. In a previous experiment, Babin et al. (2003) tested several alternative food sources, including $C$. pentandra twigs, $D$. dewevrei fruits and cocoa plant parts, in an attempt to rear $S$. singularis, the prevalent species in Cameroon. Only young shoots and fresh pods from cocoa were acceptable plant sources. Consequently, it was decided to develop a new rearing method using these plant materials.

The life cycle of $S$. singularis has been described by many authors (Raw 1959; Entwistle 1972; Youdeowei 1973; Collingwood 1977; Lavabre 1977; Nwana and Youdeowei 1977; Babin et al., in press). Eggs are usually completely buried in the host plant tissues and only two respiratory horns and the domed opercule are exposed. The incubation period is about 17 days. There are five nymphal instars, each requiring 3-6 days for completion. Females begin to lay eggs about 1 week after emergence. The adults live for about 3 weeks. However, because of the great difficulty of rearing $S$. singularis, there is a significant variability in recorded data of both fecundity and survival. The intrinsic rate of increase $(r)$ is a basic parameter commonly used to measure the growth of a population given a specified set of physical conditions and in an unlimited environment (Birch 1948). Several traits of the insect life-history, such as survival rate, sex ratio and fecundity can be estimated using this parameter (Elkinton 1993; Campos et al. 2003).

The objectives of the present work were: (i) to develop a method for rearing cocoa mirids, (ii) to assess the performance of this method through the calculation of life-table parameters and (iii) to investigate the relationship between rearing performance, especially female fecundity, and climatic conditions.

\section{Materials and Methods}

\section{Study site}

This work was conducted at the Laboratory of Entomology of the Institute for Agricultural Research for Development (IRAD), Nkolbisson research centre, near Yaoundé, southern Cameroon. The climate is equatorial with a bimodal rainfall pattern. Daily temperature is more or less constant throughout the year, with an average of about $26^{\circ} \mathrm{C}$. Rainfall occurs mainly during two rainy seasons, from April to June and from September to November.

\section{Plant source}

We used attached cocoa pods on trees for the rearing of adults, egg laying and maturation and pods and shoots collected from the same trees and transferred to an insectary for nymph rearing and adult mating. The trees belonged to an on-station genotypes plot, with lines of 15 unshaded 40 years old cocoa clones, free of any insecticide application. The genetic diversity of cocoa plants, with different fruiting times, provided a permanent food source for rearing.

\section{Insect collection}

Rearing started in June 2003, with the collection of about 50 second, third, fourth and fifth nymphal stages of $S$. singularis from a cocoa farm near Nkolbisson. First nymphal stages were not collected because of their fragility, which generally causes high mortality during handling. The insects were collected early in the morning in order to protect them from desiccation during transportation to the laboratory. Collection of mirids was done at the pod/trunk interface, underneath the pod peduncle (fig. 1) and in the bark crevices of cocoa trees. Nymphs were 


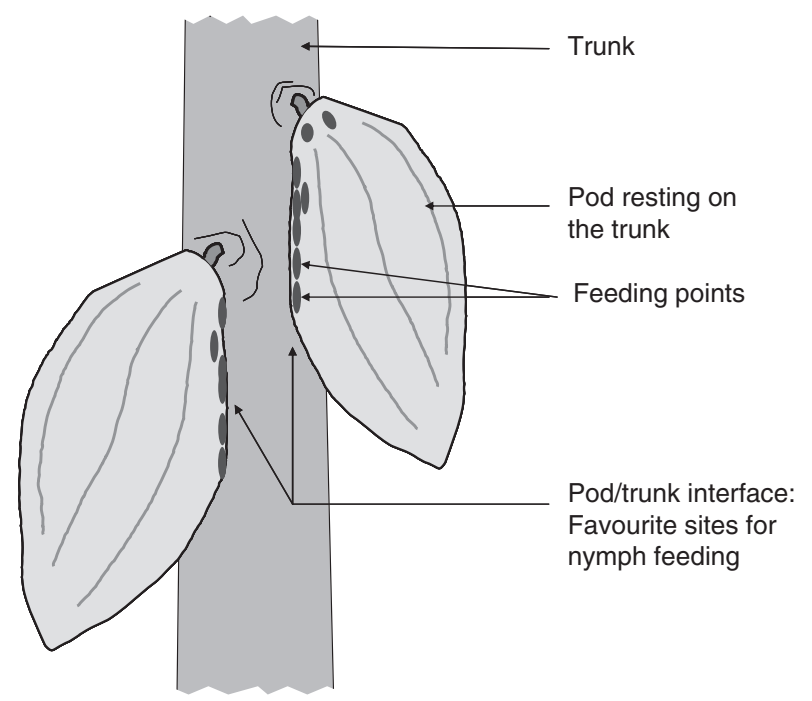

Fig. 1 Details of the cocoa trunk showing nymphs and adults favourite feeding sites. During on-farm collection, these sites are the most first explored.

collected with a fine camel hair brush and transferred to a ventilated plastic box $(30 \times 15 \times 10 \mathrm{~cm})$ containing sections of young orthotropic cocoa shoots (chupons) as food source. Chupons were wedged in the box to prevent any movement that could harm the insects.

\section{Rearing method}

Newly collected nymphs were placed in three 7.3-1 plastic containers (Ø $25 \mathrm{~cm}, 15 \mathrm{~cm}$ deep) containing each three freshly collected pods and 15-20 nymphs. The plastic containers were stored in an insectary (climatic chamber, $T=24.7 \pm 0.9^{\circ} \mathrm{C}, \quad \mathrm{RH}=84.5 \pm$ $6.8 \%$, photoperiod: 12 : $12 \mathrm{~L}: \mathrm{D}$ ) (fig. 2). Ventilation was provided through a circular hole $(\varnothing 15 \mathrm{~cm})$ at the middle of the lid of the container, covered with mousseline. Pods were changed every 7-10 days, depending on the extent of feeding damage. The bottom of each container was lined with absorbent paper to prevent water condensation. Nymph development was monitored daily. Newly moulted females were removed and kept separately until sexual maturity (5-6 days) in ventilated plastics boxes $(7 \times 10 \times 2 \mathrm{~cm})$, containing three sections of young cocoa shoots. Cocoa shoots were changed every 2 days. Subsequently, a 1-2 days old adult male was introduced into each box for mating. Older males (3-10 days old) were used when younger ones were not available. After $24 \mathrm{~h}$, both adults were transferred to attached cocoa pods in mousseline sleeve cages (fig. 3), in the field.

After a minimum of 16 days (expected hatching time), the sleeve cages were checked daily in order

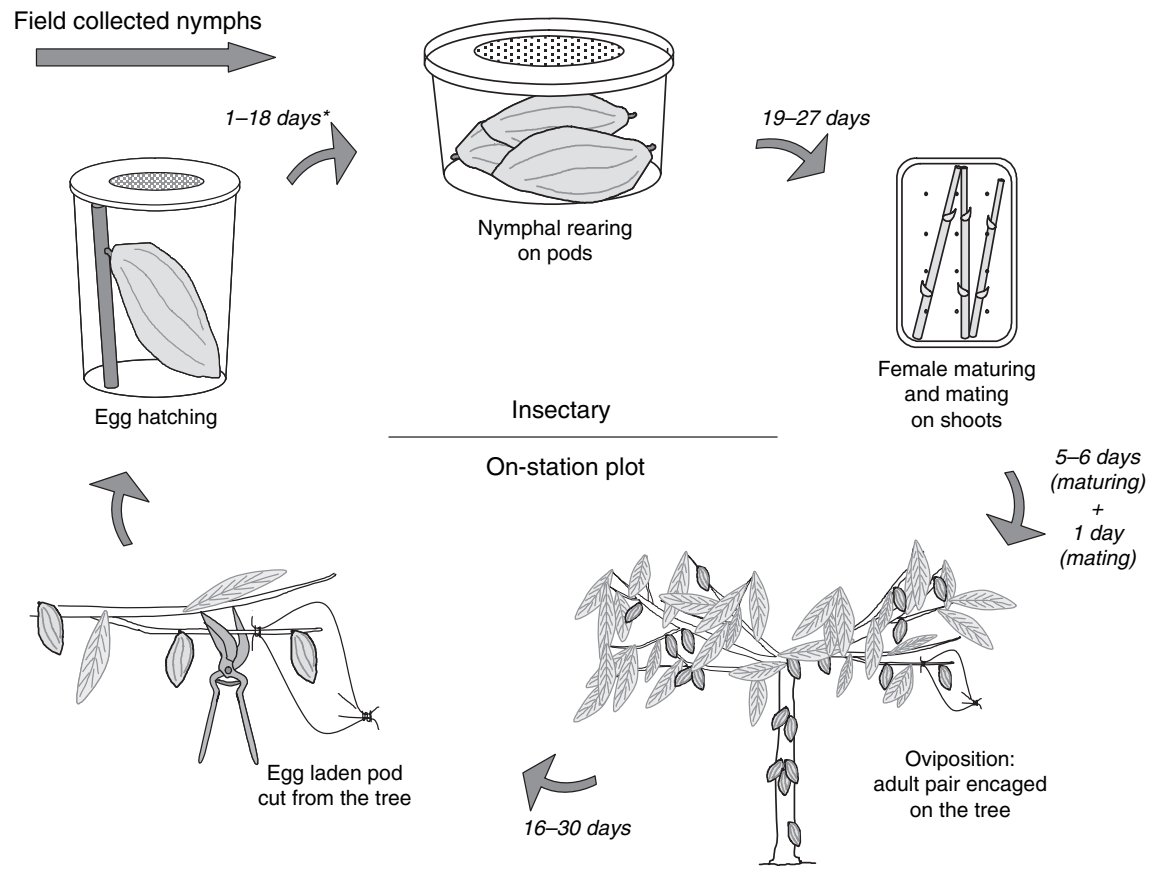

Fig. 2 Rearing procedure of Sahlbergella singularis used in the insectary and in the field. 
Fig. 3 Details of the nymph production technique showing favourite sites for oviposition and feeding of females. Adults were enclosed in pairs in the sleeve cage and allowed to feed and lay eggs until the hatching of first nymphs.

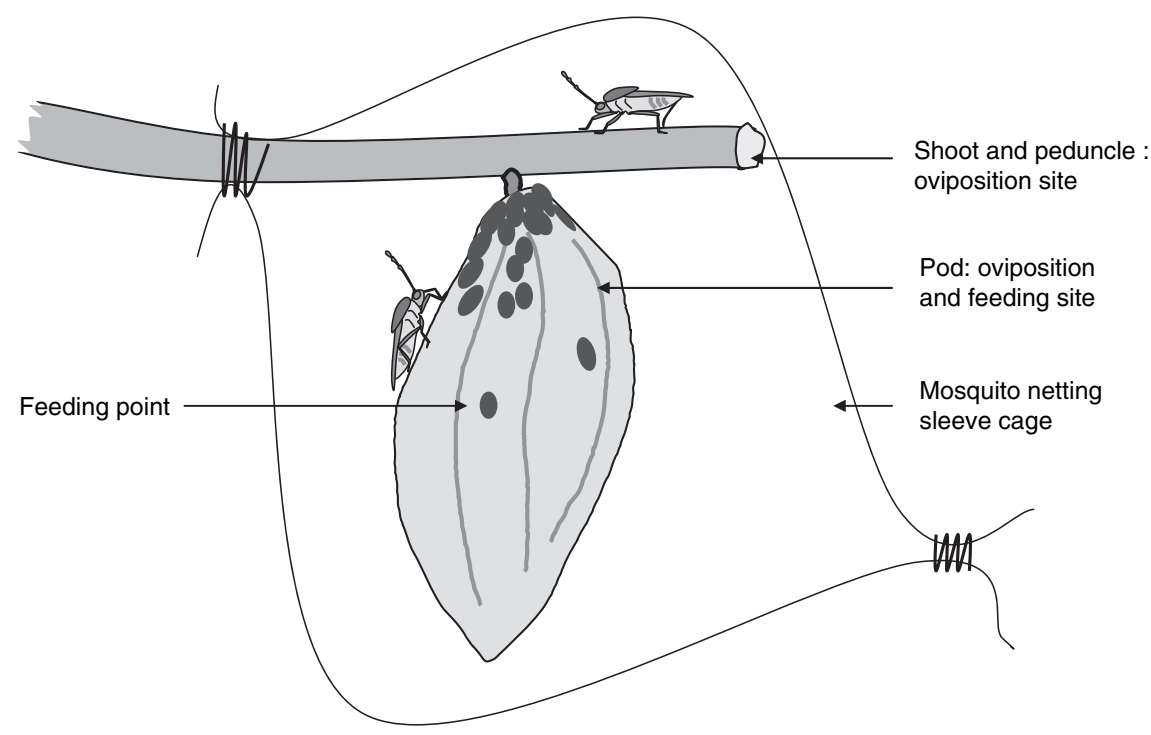

to detect newly hatched nymphs. When one or more nymphs were detected, the pod was cut from the tree and taken to the insectary. In the insectary, the collected pods were kept vertically in 4.5 -1 buckets (Ø $17 \mathrm{~cm}, 20 \mathrm{~cm}$ deep), ventilated through a circular hole $(\varnothing 15 \mathrm{~cm})$ at the middle of the lid, covered with mousseline (fig. 2). The bottom of each bucket was lined with absorbent paper to prevent water condensation. The buckets were checked daily and second instar nymphs were removed with a fine camel hair brush to the nymphs rearing cages (7.3-1 bowls). Nymphs from the first instar were not handled because of their fragility.

\section{Life-table analyses to assess rearing performance}

\section{Life-table parameters:}

Life-table analysis was used to assess the performance of our rearing technique. In this study, egg survival was not assessed and it was assumed to be 1. Nymphal survival parameters were obtained from a cohort of 305 nymphs monitored in the insectary. The proportion of nymphs surviving to adult stage was used as the $l_{x}$ value in the life tables. A sex ratio of $1: 0.71$ was calculated based on surviving adults. As climate might influence female fecundity and rearing performance, fecundity was assessed at different times during the year, with contrasting climatic conditions. Fecundity data were obtained from 14 females of the first reared generation (Gl), 24 of the fifth generation (G5) and 52 of the seventh generation (G7). Females from generations G1, G5 and G7 developed between June and July 2003, January-February and April-May 2004, respectively.
Daily minimum and maximum temperatures and rainfall were recorded at the station during the study period. The number of nymphs produced per female (of known age at $x$ days) was divided by 1.71 (sex ratio $\mathrm{F}: \mathrm{M}=1: 0.71$ ) in order to obtain the number of females $\left(m_{x}\right.$ value). The life-table parameters were calculated using the method of Birch (1948), Elkinton (1993) and Sundararaju and Babu (1998). The gross reproductive rate (GRR), defined as the average number of daughter nymphs produced by a living female throughout her entire reproductive period, was computed as: $\sum m_{x}$. The net reproductive rate $\left(R_{0}\right)$ was estimated from $\sum l_{x} m_{x}$, and was the net rate of increase per generation. The generation time $\left(T_{\mathrm{c}}\right)$ expressed as the mean time between the birth of parents and the birth of offspring was assessed using: $\sum\left(x l_{x} m_{x}\right) / R_{0}$, and the intrinsic rate of increase $(r)$ was estimated using the equation: $\sum\left(\mathrm{e}^{-r x} l_{x} m_{x}\right)=1.0$. In this equation, the $r$ value was obtained by successive approximations, such that the left-hand side of the equation was sufficiently close to 1.0; we therefore derived from $r$ the population doubling time $\left(T_{\mathrm{d}}\right)$ as follows: $\ln (2) / r$.

\section{Fecundity}

Our rearing method did not allow to monitor egg laying and development. Therefore, we assessed fecundity by nymph production parameters. The daily number of nymphs were counted and recorded for each female of generations G1, G5 and G7. The proportion of reproductive females and the total number of nymphs per female were assessed per generation as well as the mean pre-hatching time. Here, pre-hatching time was defined as the time 
between the day the mated female was transferred to the plot and the day of the emergence of the first nymph.

\section{Statistical analyses}

Proportions of reproductive females among generations were compared using a chi-square test of independence. Data for fecundity, pre-hatching time and climate were tested for normality using an univariate analysis and the W-test for normality (Shapiro and Wilk 1965; SAS Institute 1987) and were log-transformed if necessary. A general linear model was used to test the effect of generation on fecundity and prehatching time and the effect of time on climate data (SAS Institute 1987). Means were subsequently separated using Duncan's multiple range test at $\mathrm{P}=0.05$.

\section{Results}

Our rearing method enabled the production of $14.6 \pm 6.7$ nymphs per female per generation for 15 consecutive generations between June 2003 and May 2005. Nymphal survival in the insectary was estimated at $68.2 \%$ and the mean duration of the nymphal development was assessed at $22.7 \pm 3.1$ days.

Table 1 displays the life-table parameters calculated with cumulated data from generations G1, G5 and G7 (column overall) and for each generation independently. The overall GRR was 9.70. Generation G7 recorded the highest GRR with 12.31, while G5 recorded the lowest with 4.79 . The overall net reproductive rate $\left(R_{0}\right)$ was 6.59 and the overall intrinsic rate of increase $(r)$ was 0.037. G7 showed a higher $r$ than G5, 0.042 vs. 0.022, respectively. The overall mean generation time $\left(T_{\mathrm{c}}\right)$ and population doubling time $\left(T_{\mathrm{d}}\right)$ were 52.1 and 18.9 days,

Table 1 Life-table parameters for Sahlbergella singularis. Parameters were calculated overall (see overall column) as well as for each generation independently (see G1, G5 and G7 columns)

\begin{tabular}{lcccc}
\hline \multicolumn{4}{c}{ Female generation } & \\
\cline { 2 - 5 } Parameters & Overall & G1 & G5 & G7 \\
\hline & & & & \\
\hline $\begin{array}{l}\text { Gross reproductive } \\
\text { rate (GRR) }\end{array}$ & 9.70 & 8.36 & 4.79 & 12.31 \\
$\begin{array}{l}\text { Net reproductive rate }\left(R_{0}\right) \\
\text { Mean generation time }\end{array}$ & 6.59 & 5.69 & 3.23 & 8.37 \\
$\begin{array}{l}\left.\text { ( } T_{\mathrm{c}}\right) \text { (in days) } \\
\text { Intrinsic rate of increase }(r)\end{array}$ & 0.037 & 0.033 & 0.022 & 0.042 \\
Doubling time $\left(T_{\mathrm{d}}\right)$ (in days) & 18.9 & 21.0 & 31.5 & 16.5 \\
\hline
\end{tabular}

respectively. G5 recorded the highest $T_{\mathrm{c}}$ and $T_{\mathrm{d}}$, with 54.1 and 31.5 days, respectively. The $r$ values indicate that the rearing population was a slow-growing population. The results also suggest that G7 had a higher growth ability than G5.

Figure 4 displays the variation of fecundity parameters between generations and the climatic patterns. The proportion of reproductive females and the mean number of nymphs per female peaked for G7 with $86.8 \%$ and $21.2 \pm 21.0 \%$, respectively. The proportion of reproductive females and the mean number of nymphs per female were significantly lower for G5 (proportion of reproductive females, $\mathrm{P}<0.001$; mean number of nymphs per female, $\mathrm{P}<0.01)$, with $45.8 \%$ and $7.9 \pm 12.5 \%$, respectively. The pre-hatching time was significantly higher in $\mathrm{G} 5(\mathrm{P}<0.01)$, with $23.7 \pm 2.2$ days as compared to $19.3 \pm 2.5$ days for $\mathrm{Gl}$ and $20.1 \pm 4.1$ days for G7.

Mean daily temperature was significantly different between generations $(\mathrm{P}<0.0001)$, with $25.6 \pm$ $1.5^{\circ} \mathrm{C}$ for $\mathrm{Gl}, 26.4 \pm 1.4^{\circ} \mathrm{C}$ for $\mathrm{G} 5$ and $27.8 \pm 1.7^{\circ} \mathrm{C}$ for G7. Mean daily rainfall was significantly lower for G5 than for G1 and G7 $(\mathrm{P}<0.0001)$, with $0.5 \pm 2.0,5.16 \pm 9.1$ and $6.34 \pm 11.1 \mathrm{~mm}$, respectively.

These results show that fecundity parameters vary to some extend with rainfall intensity suggesting a relationship between these variables.

\section{Discussion}

The first purpose of this study aimed at developing an improved rearing method for the cocoa mirid $S$. singularis. We have been able to establish a practical rearing method, providing sufficient numbers of insects for the duration of 2 years for large-scale laboratory experimentation. The rearing techniques described in the past did not permit continuous rearing. In most of the techniques for egg laying described in the past, females were enclosed in mousseline sleeve cages on 6-9 months old cocoa seedlings (Raw 1959; Houillier 1964; Prins 1964; Youdeowei 1964). However, cocoa seedlings survival was strongly affected by female feeding and a significant part of the eggs was lost. Moreover, as a large cocoa nursery was required for seedling supply, this technique was labour-consuming, expensive and finally abandoned. In 1965, Bruneau de Miré enclosed 15 mature cocoa trees in a large mosquito net cage. As the population of the first generation exceeded more than 100 mirids per tree, extensive feeding damage quickly jeopardized the survival of 
Fig. 4 Proportion of reproductive females (\%), total number of larvae per female and pre-hatching time (in days) for the three monitored generations of females G1, G5 and $\mathrm{G} 7$, indicated in grey, as well as average daily temperature and daily rainfall patterns. Values followed by a same letter do not differ at $P=0.05$. Comparisons in one-line graph only.

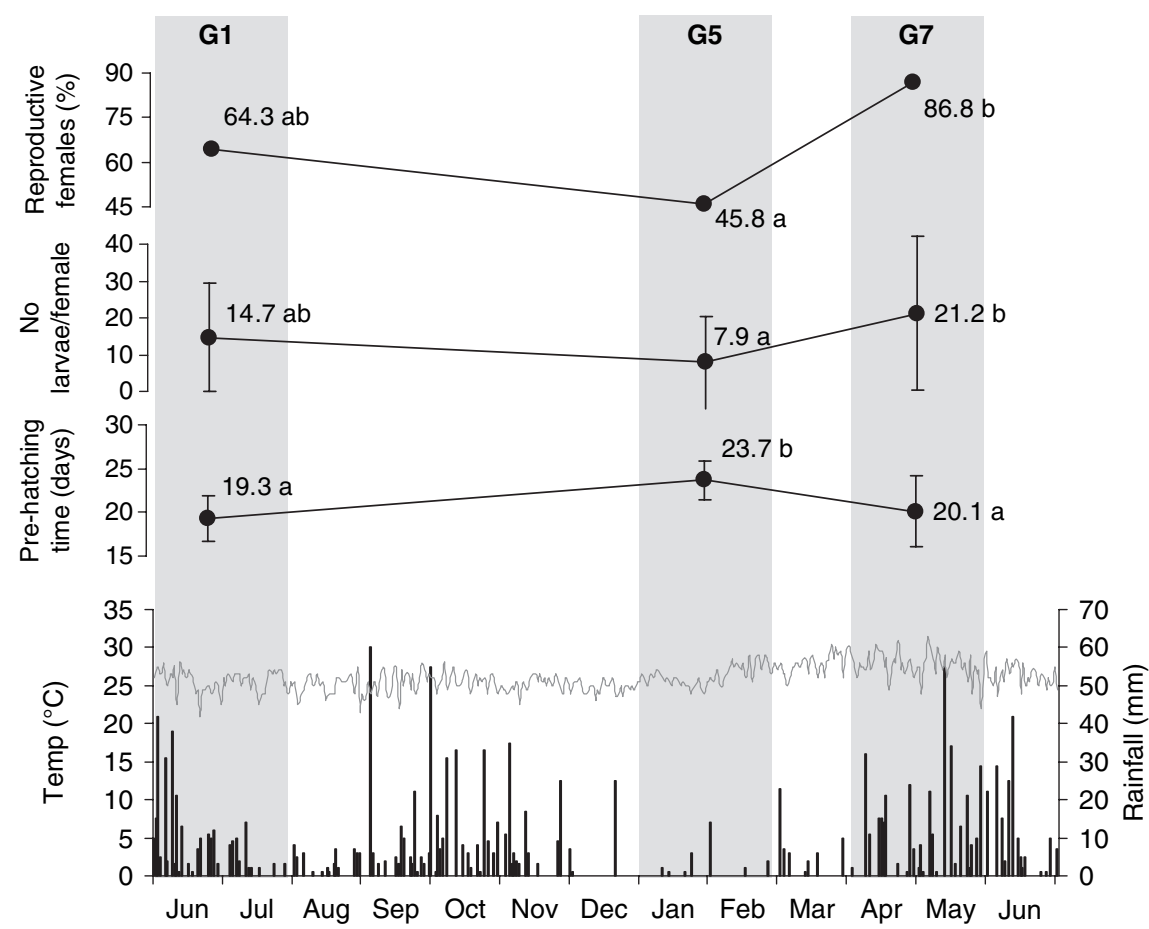

trees. This technique was thus not practicable for a long-term rearing, but it stressed the need to control the growth of the rearing population. Piart (1970) succeeded in rearing $D$. theobroma in the laboratory for several generations, using ceiba twigs (C. pentandra) as a food supply. The sections of orthotropic ceiba shoots developed when they were dipped in water and thus permitted the maturation of eggs and the feeding of young nymphs. However, we failed to rear $S$. singularis on ceiba shoots. Although nymphs and adults fed on ceiba twigs, females did not lay eggs on these plant parts. Moreover, twig supply quickly became a problem, as ceiba trees did not grow near the laboratory. Consequently, cocoa was the only plant source adopted for our rearing method (Babin et al. 2003).

As summarized by Piart (1977), specific climatic conditions, constant food supply and a minimum handling of nymphs, which are very fragile, are crucial factors for success. Unsuccessful attempts reported in the past suggest that egg maturation conditions are a major rearing constraint as well. Females insert eggs in cocoa living tissues, and egg development requires healthy tissues to be completed (Piart 1977). The lifetime of detached cocoa plant tissue does not allow the maturation of eggs, which takes at least 15 days for S. singularis (Lavabre 1977), especially as these plant parts are strongly damaged by female feeding. Attempts to use cocoa seedlings as egg laying support remained unsuccessful, because of the fragility of seedlings, which were quickly affected by mirid feeding.

In the method proposed here, egg laying and egg maturation phases were taking place on attached cocoa pods on trees, in such a way that adults fed on fresh pods during egg laying, while eggs were inserted through the bark of the branch enclosed with the pod and in the pod peduncle (fig. 3). Subsequent egg maturation thus occurred most of the time in healthy plant tissues and hatching of nymphs was improved. Moreover, once hatched, young nymphs could immediately feed on the pod. The pod and the part of the branch enclosed in the sleeve cage were then transferred to the insectary, with the aim to limit handling of young nymphs while keeping them under favourable climatic conditions for their development. It has been suggested that nymphs' development requires a relative humidity rate $>80 \%$ (Piart 1970; Entwistle 1972; Lavabre 1977), which can't be maintained under natural conditions during the dry season.

While on the trees, adults were enclosed on pods in sleeve cages. Mirid damage was then restricted to targeted parts of the trees and the health of trees was not affected by recurrent infestations. However, consequently, the method proposed here requires mature and sturdy cacao trees. Moreover, trees must be free of any insecticide spraying and must have 
different fruiting times to provide a permanent food source for the rearing. This prerequisite could be met by using trees from different genotypes. However it is obvious, that this rearing method is probably only appropriate for tropical regions, where cocoa can be grown in natural conditions. As the biology of $D$. theobroma is closely related to that of $S$. singularis, we regard it possible to easily adapt our method to this species. Consequently, African cocoaproducing countries faced with mirid problems should greatly benefit by this method. However, further studies have to be conducted to develop artificial diets, which may enable the rearing of cocoa mirids in laboratories located in temperate countries.

The second purpose of the study was to assess the rearing performance. For this reason, we calculated life-table parameters that are commonly used to measure growth of insect populations. To the best of our knowledge, life-table data are not yet available for cocoa mirids. Piart's method (1970) enabled the production of roughly seven females per each female from the previous generation. Despite the fact that the calculation method was different, we recorded a similar net reproductive rate $\left(R_{0}\right)$ of 6.59. Intrinsic rates of increase have been calculated for some members of the Miridae family. Sundararaju and Babu (1998) estimated the $r$ value to be between 0.0086 and 0.126 for Helopeltis antonii Sign., depending on the host plant. Fleischer and Gaylor (1988) recorded a $r$ value of 0.058 for Lygus lineolaris (Palisot de Beauvois) on cotton. The low intrinsic rate of increase recorded for $S$. singularis and other mirid species suggests a slow multiplying species (Elkinton 1993). Our results apply to low mirid densities generally observed on cocoa farms (Entwistle 1972; Lavabre 1977). Bruneau de Miré (1970) suggested that the drop of $S$. singularis populations during the dry season could be due to the considerable damage caused by the insects. A low intrinsic rate of increase may have been selected for in S. singularis to avoid high population numbers, which would exhaust the food supply under natural conditions, as suggested by Birch (1948) for insect populations.

We also found significant variations in the lifetable parameters for generations monitored. The GRR and the net reproductive rate $\left(R_{0}\right)$ were almost three times higher for G7 than for G5. The population doubling time was almost two times longer for G5 than for G7. Rainfall seems to have an effect on the reproductive potential of the reared populations. Rainfall conditions prevailing for generation G1 and G7 were probably more favourable. In most of tropical regions, rainfall and relative humidity are the major factors influencing the development of insect populations, far exceeding the influence of temperature (Elkinton 1993). As $S$. singularis females lay their eggs inside the host tissues, humidity probably does not directly influence their survival and development. The fecundity of young females, however, may be affected by the sudden humidity change when being transferred from the insectary to the plot. Moreover, the reproductive ability of females can be directly affected by the quality of food consumed by immature stages (Campos et al. 2003). Consequently, rainfall and humidity strongly interact with food supply and act as modulators of development (Tauber et al. 1998). In our case, the quality of cocoa pods should have been negatively affected by water stress during the dry season, thereby influencing rearing performance. In the field, mirid densities are lower during the dry season as compared with the wet season (Williams 1954; Lavabre et al. 1962; Gibbs et al. 1968; Bruneau de Miré 1970). Mirid densities increase when trees bear fruits, which provide constant food and oviposition sites (Williams 1953a; Lavabre 1977; Piart 1978). However, some studies found that mirid populations develop similarly on unproductive cocoa (Williams 1954), or when pods are gradually removed from the trees (Bruneau de Miré 1977). Consequently, it is likely that behavioural aspects, and especially the dispersion of adults, interact with environmental and food supply factors (Bruneau de Miré 1977).

The demographic parameters of the populations reared in our study suggested that low mirid densities in the field could be related to the low intrinsic rate of increase of this species. However, additional studies are needed to understand the effect of environmental and food supply factors on life-history traits of cocoa mirids. A study specifically dealing with these parameters is currently in progress in our laboratory.

\section{Acknowledgements}

We would like to thank the personnel of the IRAD research station at Nkolbisson, for the use of their land and facilities and for their assistance in maintaining the cocoa plot. Special recognition is extended to Michel Ndjalla, Sébastien Zomo, Victor Ondoa, Benoît Owona and Junior Zomo, the technical workforce of the Laboratory of Entomology. We are especially grateful to Martijn Ten Hoopen for his assistance on English writing. This research was funded by CIRAD. We acknowledge the comments 
of two anonymous reviewers, which improved previous versions of the manuscript.

\section{References}

Babin R, Dibog L, Bisseleua H, 2003. Mise au point d'une méthode d'élevage de Sahlbergella singularis Hagl. (Hemiptera: Miridae) au laboratoire. Résultats préliminaires des travaux menés au Cameroun. Proceedings of the 14th International Cocoa Research Conference, Accra, Ghana, October 2003, 1333-1440.

Babin R, Dibog L, Bisseleua H, 2006. Description et évaluation d'une nouvelle méthode d'élevage, et éléments de biologie de Sahlbergella singularis Hagl. (Hemiptera: Miridae), principal ravageur du cacaoyer au Cameroun. Proceedings of the 15th International Cocoa Research Conference, San Jose, Costa Rica, October 2006 (in press).

Birch LC, 1948. The intrinsic rate of natural increase of an insect population. J. Anim. Ecol. 17, 15-26.

Bruneau de Miré P, 1965. Les recherches sur l'écologie des mirides du cacaoyer (Sahlbergella singularis Hagl. et Distantiella theobromae Dist.) en République Fédérale du Cameroun. IFCC report, November 1965, 11 pp.

Bruneau de Miré P, 1970. Observations sur les fluctuations saisonnières d'une population de Sahlbergella singularis au Cameroun. Café Cacao Thé. 14, 202-207.

Bruneau de Miré P, 1977. La dynamique des populations de Mirides et ses implications. In: Les Mirides du Cacaoyer Ed. by Lavabre EM, G-P Maisonneuve et Larose, Paris, 171-186.

Campos WG, Schoereder JH, Picanço MC, 2003. Performance of an oligophagous insect in relation to the age of the host plant. Neotrop. Entomol. 32, 671-676.

Collingwood CA, 1977. African mirids. In: Les Mirides du Cacaoyer Ed. by Lavabre EM, G-P Maisonneuve et Larose, Paris, 71-76.

Cross DJ, King ABS, 1971. Capsid rearing. In: Cocoa capsids in West Africa. Report of the International Capsid Research Team, 1965-1971, Cocoa, Chocolate \& Confectionery Alliance, London, 55-61.

Crowdy SH, 1947. Observation on the pathogenicity of Calonectria rigidiuscula (Berk. and Br.) Sacc. on Theobroma cacao L. Ann. Appl. Biol. 34, 45-59.

Elkinton JS, 1993. Insect population ecology. An African perspective. ICIPE Science Press, Nairobi, Kenya.

Entwistle PF, 1972. Pests of cocoa. Longman Group Ltd, London.

Fleischer SJ, Gaylor MJ, 1988. Lygus lineolaris (Heteroptera: Miridae) population dynamics: nymphal development, life tables, and Leslie matrices on selected weeds and cotton. Environ. Entomol. 17, 246-253.

Gibbs DG, Pickett AD, Leston L, 1968. Seasonal population changes in cocoa capsids (Hemiptera: Miridae) in Ghana. Bull. Entomol. Res. 58, 279-293.
Houillier M, 1964. Régime alimentaire et disponibilité de ponte des Miridés dissimulés du cacaoyer. Rev. Path. Vég. Ent. Agr. Fr. 43, 195-200.

Kumar R, Ansari AK, 1974. Biology, immature stages and rearing of cocoa-capsids (Miridae: Heteroptera). Zool. J. Linn. Soc. 54, 1-29.

Lavabre EM, 1969. Progrès récents dans l'élevage en laboratoire de quelques déprédateurs des cacaoyères africaines. Bull. Phytos. FAO. 17, 132-135.

Lavabre EM, 1977. Les mirides du cacaoyer. Ed. by Lavabre EM, G-P Maisonneuve et Larose, Paris, 366 p.

Lavabre EM, Decelle J, Debord P, 1962. Recherches sur les variations des populations de Mirides en Côte d'Ivoire. Café Cacao Thé. 6, 287-295.

Lotodé R, 1969. Etude statistique de l'évolution d'une population de Mirides. Café Cacao Thé. 13, 216-220.

Nwana IE, Youdeowei A, 1977. The effect of relative humidity on the development and survival of the pre-imaginal stages of Bathycoelia thalassina (H-S) (Pentatomidae) and Sahlbergella singularis Hagl. (Miridae) in Nigeria. J. Nat. Hist. 11, 445-449.

Nwana IE, Youdeowei A, 1978. The spatial distribution of three species of Heteroptera in a cocoa farm in Ibadan, Nigeria. Nigerian J. Entomol. 3, 27-33.

Padi B, Owusu GK, Kumah NK, 1996. A record of Desplatsia dewevrei (De Wild \& Th. Dur.) (Tiliales: Tiliaceae) as an alternative and potential breeding host plant for the cocoa mirid Sahlbergella singularis Hagl. Proceedings of the 12th International Cocoa Research Conference, Salvador, Bahia, Brazil, 31-37.

Piart J, 1970. Etude de quelques caractéristiques biologiques du miride du cacaoyer Distantiella theobromae Dist. au moyen d'un élevage au laboratoire. Café Cacao Thé. 14, 28-36.

Piart J, 1977. Elevage au laboratoire des Mirides du cacaoyer. In: Les Mirides du Cacaoyer Ed. by Lavabre EM, G-P Maisonneuve et Larose, Paris, 203-211.

Piart J, 1978. Fluctuations saisonnières de la fécondité chez le Miride du cacaoyer Distantiella theobroma Dist. Café Cacao Thé. 22, 195-201.

Prins G, 1964. A laboratory rearing method for the cocoa mirid Distantiella theobroma (Dist.) (Hemiptera: Miridae). Bull. Entomol. Res. 55, 615-616.

Raw F, 1959. An insectary method for the rearing of cacao mirids, Distantiella theobroma (Dist.) and Sahlbergella singularis Hagl. Bull. Entomol. Res. 50, 11-12.

SAS Institute, 1987. SAS user's guide: statistics, version 9.1.3. SAS Institute, Cary, NC.

Shapiro SS, Wilk MB, 1965. An analysis of variance test for normality (complete samples). Biometrika 52, 591-610.

Sundararaju D, Babu PCS, 1998. Life table studies of Helopeltis antonii Sign. (Heteroptera: Miridae) on neem, guava and cashew. J. Entomol. Res. 22, 241-244. 
Tauber MJ, Tauber CA, Nyrop JP, Villani MG, 1998. Moisture, a vital but neglected factor in the seasonal ecology of insects: hypotheses and tests of mechanisms. Environ. Entomol. 27, 523-530.

Williams G, 1953a. Field observations on the cacao mirids, Sahlbergella singularis Hagl. and Distantiella theobroma (Dist.), in the gold coast. Part I: Mirid damage. Bull. Entomol. Res. 44, 101-119.

Williams G, 1953b. Field observations on the cacao mirids, Sahlbergella singularis Hagl. and Distantiella theobroma (Dist.), in the gold coast. Part II: geographical and habitat distribution. Bull. Entomol. Res. 44, 427437.

Williams G, 1954. Field observations on the cacao mirids, Sahlbergella singularis Hagl. and Distantiella theobroma
(Dist.), in the gold coast. Part III: population fluctuations. Bull. Entomol. Res. 45, 723-744.

Youdeowei A, 1964. Progress in the laboratory rearing of cocoa mirids in Nigeria. Proceedings of the Conference on Mirids and other Pests Cocoa, Ibadan, Nigeria, 98-100.

Youdeowei A, 1971. Studies on the pattern of distribution of the cacao capsid, Sahlbergella singularis Hagl. in relation to light intensity in an isolated plot of cacao, Theobroma cacao L. J. West African Sci. Assoc. 16, 5-12. Youdeowei A, 1973. The life cycles of the cocoa mirids Sahlbergella singularis Hagl. and Distantiella theobroma Dist. in Nigeria. J. Nat. Hist. 7, 217-223. 